\title{
Giresun ilinde yetişen yerel bezelye (Pisum sativum L.) popülasyonlarının fizyolojik ve morfolojik karakterizasyonunun belirlenmesi*
}

\author{
Nuri YILMAZ ${ }^{1}$, Havva Vildan KILINÇ² \\ *Havva Vildan KILINÇ’’ın yüksek lisans çalışmasından alınmıştır. \\ 10rdu Üniversitesi Ziraat Fakültesi Tarla Bitkileri Bölümü, ORDU \\ ${ }^{2}$ Gıda Tarım ve Hayvancılık Bakanlığı, Altınordu İlçe Gıda Tarım ve Hayvancllık Müdürlüğü ORDU \\ Alınış tarihi: 27 Eylül 2017, Kabul tarihi: 20 Aralık 2017 \\ Sorumlu yazar: Nuri YILMAZ, e-posta: y_nuri@hotmail.com
}

\section{$\ddot{0} \mathbf{z}$}

$\mathrm{Bu}$ çalışma 2012-2013 yetiştirme döneminde Giresun ilinde yetișen yerel bezelye genotiplerinin morfolojik karakterizasyonunun belirlenmesi amaciyla Ordu Üniversitesi Ziraat Fakültesi deneme arazisinde kurulmuştur. Giresun'un farklı ilçeleri 2012 yılı Eylül-Ekim aylarında gezilerek, tane tüketim amacıyla yetiştirilen bezelye genotiplerinin tohumları yerel pazarlar dolaşılarak materyal olarak toplanmıştır. Materyaller toplanan 24 adet genotip ile kontrol olarak değerlendirilen 3 adet ticari çeşitten oluşmaktadır. Tohum ekimleri her genotip 2 sıra olacak şekilde Augmented Deneme Desenine göre kurulmuştur. Çalışma sonunda çıkış süresi 1019 gün, çiçeklenme gün süresi 65-145 gün, vejetasyon süresi 160-210 gün, bitki boyu 56.75$130.25 \mathrm{~cm}$, gövde çapı 4.0-7.2 mm, dal sayısı 3.056.75 adet/bitki, ilk bakla yüksekliği $9.70-51.95 \mathrm{~cm}$, bakla boyu $6.45-11.25 \mathrm{~cm}$, bakla genişliği 9.887$20.914 \mathrm{~mm}$, tohum boyu 6.924-11.103 $\mathrm{mm}$, tohum genişliği 7.585-10.780 mm olarak belirlenmiştir. Çalışmada özellikle verim yönünden, G1, G15, G16 ve G18 genotipleri kullanılan çeşitlerden ve diğer genotiplerden daha yüksek performans göstermiştir. Söz konusu genotipler bölge için ümitvar gözükmektedir. Ayrıca ıslah açısından verimi ön planda olan bu genotipler islah materyali olarak değerlendirilebilir.

Anahtar kelimeler: Kuru Bezelye, Pisum sativum L., Genotip, Karakterizasyon
Determination of fizyological and morphological characterization of local peas (Pisum sativum L.) types grow the provice in Giresun

\begin{abstract}
This study was conducted in research area of Agriculture Faculty, Ordu, during the 2012-2013 to determination of fizyolojical and morphological characterization of local peas types grow the provice in Giresun. Different districts of giresun in September -October of 2012, grain consumption in order to navigate through the seeds of pea genotypes grown changing entrenched attitudes with material collected in the local markets. The collected materials will be evaluated as check with 24 pieces of genotype 3 consists of commercial varieties. Seeding will be Augmented each genotype 2 Trial established. As a result of study; output period 10-19 days, flowering period 65-145 days, vegetation period 160-210 days, plant height $56.75-130.25 \mathrm{~cm}$, body diameter 4.0-7.2 $\mathrm{mm}$, number of branches 3.05-6.75, first pods height 9.70-51.95 cm, pods height $6.45-11.25 \mathrm{~cm}$, pods length 10.887-20.914 $\mathrm{mm}$, seed height $6.924-11.103 \mathrm{~mm}$, seed length 7.585-10.780 $\mathrm{mm}$ respectively. In the study, G1, G15, G16 and G18 genotypes showed higher performance than varieties and the other genotypes in terms of yield. These genotypes are promising fort he region and can be used as a breeding materials.
\end{abstract}

Key words: Dry peas, Pisum sativum L., genotype, characterization 


\section{Giriş}

Ülkemiz tarım alanlarının \%10'unu kapsayan yemeklik tane baklagil bitkileri, gerek sahip oldukları yüksek protein içeriği nedeniyle beslenme ve gerekse azot bağlama özelliklerinden dolayı ekim nöbeti sistemlerinde aranan bitkilerdir. Yemeklik tane baklagiller binlerce yıldır insanların diyetlerinin önemli bir kısmını oluşturmuştur. Yararlanma ve kullanım şekillerine göre özellikle proteince zengin bitkilerdir. İnsan beslenmesinde hayvansal proteinler, bitkisel proteinlerden daha uygun olmasına rağmen gerekli olan hayvansal proteinin sağlanamadığı yerlerde besinleri biyolojik olarak tamamlayacak besinlere gereksinim vardır. Yemeklik tane baklagiller bu yönden çok uygundurlar (Çiftçi ve Adak, 2009).

Yemeklik tane baklagiller içerisinde önemli bir yere sahip olan bezelye; 2014 yll FAO istatistiklerine göre; dünyada kuru bezelye olarak 6.93 milyon ha ekim alanı, 11.18 milyon ton üretimi ve verimi 1613 $\mathrm{kg} / \mathrm{ha}$ verime sahiptir. Türkiye'de kuru bezelye ekim alanı 1088 ha, verim $268 \mathrm{~kg} / \mathrm{da}$, üretim 2919 ton'dur (Anonim, 2016). Kuru bezelye tarımı yapan ülkeler içerisinde ülkemiz, ekiliş alanı ve verim bakımından son sıralarda yer almaktadır. Oysaki Anadolu bezelye yetiştiriciliğine uygun ekolojik şartları taşır ve ayrıca bezelyenin orjin merkezlerinden biridir.

Ekim alanındaki azlığa paralel olarak, ülkemizde tarımı yapılan yemeklik baklagil cinsleri içersinde bezelye, yerli tescilli çeşit sayısı bakımından en fakir olanıdır. Ülkemizde kuru tane amaçlı kullanıma yönelik hiçbir tescilli çeşit yokken, taze tüketim amaçlı bugüne kadar 11 adet çeşit, tescilli veya üretim izinli olarak piyasada yer almıştır. Bunlardan da sadece bir tanesi ülkemizde tescil edilmiştir. Oysa Akçin (1988)'in bildirdiğine göre ülkemizin içinde bulunduğu Yakın Asya ve Akdeniz gen merkezleri birçok bitki için olduğu gibi bezelyenin de gen merkezidir. Bu materyallerin ve bitkisel çeşitliliğin günümüzden geleceğe aktarılması bunların korunması, saklanması ve değerlendirilmesi tarımın sürdürülebilirliği için en önemli kaynaklardır.

Yetiştikleri bölgelerin ekolojik koşullarına tam olarak uyum sağlayan genetik materyal tarımın dolayısıyla insanlığın geleceğinin güvencesidir (Özgen ve ark., 2000). Bitki ıslahı çalışmalarının esasını genetik kaynaklardaki çeşitlilik oluşturmaktadır. Primitif formlar ve yerel çeşitler genetik taban olarak kültür bitkilerinin ileride çıkabilecek sorunlarının giderilmesinde veya kültür bitkilerine yeni özelliklerin aktarılmasında önemli genetik kaynaklardır (Akgün ve ark., 1998). Türkiye gerek coğrafik yapısı gerekse sahip olduğu değişik ekolojik koşullar nedeniyle bitkisel gen kaynakları bakımından dünyada çok önemli bir konuma sahiptir (Özgen ve ark., 2000). Yaygın olarak tarımı yapılan 6 yemeklik tane baklagil cinsinden 4' ünün anavatanıdır.

$\mathrm{Bu}$ çalışmada amacımız; Giresun ilinden toplanan yerel bezelye genotiplerine ait tanımlayıcı bilgilerin kayıt altına alınması, agronomik ve morfolojik özelliklerinin belirlenmesi ve yüksek verimli genotipler tespit edilerek bundan sonraki sslah ve çeşit geliştirme konusunda yapılacak çalışmalara yararlı olabilecek alt yapı sağlayacak olmasıdır.

\section{Materyal ve Yöntem}

\section{Materyal}

Deneme, Ordu şehir merkezine yaklaşık $5 \mathrm{~km}$ mesafedeki Ordu Üniversitesi Ziraat Fakültesi uygulama alanında yürütülmüştür. Deneme alanının toprak tekstürü tınlı yapıda, Nötr reaksiyon özelliğindedir. Potasyum miktarı yüksek, organik madde ve fosfor miktarı azdır (Anonim, 2012).

Ordu ilinde kıyıya paralel olarak uzanan dağlar nedeniyle, ilde kıyı kesimde ve iç kesimde farklı iklim yaşanmaktadır. Denemenin yürütüldüğ̈ü kıyı kesimde kışlar ılıman, yazlar nispeten serin ve her mevsim yağışlı geçmektedir. Denemenin yürütüldüğü 2012-2013 vejetasyon döneminde en düşük ortalama sıcaklık $9.4^{\circ} \mathrm{C}$ ile Ocak ayında, en yüksek ortalama sıcaklık ise $17.9^{\circ} \mathrm{C}$ ile Mayıs ayında gözlenmiştir. $\mathrm{Bu}$ döneme ait ortalama sıcaklık ise $12.5^{\circ} \mathrm{C}$ olarak kaydedilmiştir (Anonim, 2013). Denemenin yürütüldüğü 2012-2013 yetiştirme sezonunda, toplam $643.8 \mathrm{~mm}$ yağış düşmüş ve en düşük yağış $21.9 \mathrm{~mm}$ ile Nisan ayında, en yüksek yağış 201.3 mm ile Kasım ayında gerçekleşmiştir. Denemenin yürütüldüğü dönemde en düşük nem \% 63.7 ile Ocak ayında en yüksek nem \% 74.2 ile Kasım ayında kaydedilmiştir (Anonim, 2013). Ordu ilinin iklim verileri bezelye yetiştiriciliği açısından uygun bir ekolojiye sahip olduğu görülmektedir. Araştırma kapsamındaki Giresun ilinin Eynesil, Görele, Tirebolu, Çanakçı, Dereli, Espiye, Keşap, Bulancak, Piraziz, Yağlıdere ve Güce ilçeleri 2012 yılı EylülEkim aylarında gezilerek, tane tüketim amacıyla yetiştirilen bezelye genotiplerinin tohumları yerel pazarlar dolaşılarak materyal olarak toplanmıştır. Toplanan materyaller 24 adet genotip ile kontrol olarak değerlendirilen 3 adet ticari çeşitten oluşmaktadır. Toplanan genotiplerin ve ticari 
çeşitlerin kayıt numaraları ve geldiği yerlerin adları Çizelge 1'de verilmiştir. Toplanan bu genotiplerin tohumları ile Geçit Kuşağı Tarımsal Araştırma Enstitüsü ve May Tohumculuk Ziraat ve Ticaret Ltd.
Şti'den temin edilen sertifikalı tohumlar (Bolero, Utrilla, Sprinter) 2012 yılı Kasım ayında tarla denemelerine alınmıştır.

Çizelge 1. Bezelye Genotiplerinin ve ticari çeşitlerin numaraları ve toplandığı yerlerin adı

\begin{tabular}{|c|c|c|c|}
\hline Genotip & Kod & İlçe & Köy \\
\hline G1 & TR2801 & Eynesil & Ören \\
\hline G2 & TR2802 & Eynesil & Kekiktepe \\
\hline G3 & TR2803 & Görele & Daylı \\
\hline G4 & TR2804 & Görele & Terziali \\
\hline G5 & TR2805 & Görele & Aralıkoz \\
\hline G6 & TR2806 & Görele & Doğankent \\
\hline G7 & TR2807 & Tirebolu & Ișıklı \\
\hline G8 & TR2808 & Tirebolu & Sultanköy \\
\hline G9 & TR2809 & Tirebolu & Halaçlı \\
\hline G10 & TR2810 & Çanakçı & Akköy \\
\hline G11 & TR2811 & Çanakçı & Egeköy \\
\hline G12 & TR2812 & Dereli & Sarıyer \\
\hline G13 & TR2813 & Dereli & Sütlüce \\
\hline G14 & TR2814 & Espiye & Çepni \\
\hline G15 & TR2815 & Espiye & Bahçecik \\
\hline G16 & TR2816 & Keşap & Töngel \\
\hline G17 & TR2817 & Keşap & Tepeköy \\
\hline G18 & TR2818 & Bulancak & Esenköy \\
\hline G19 & TR2819 & Bulancak & Güneyköy \\
\hline G20 & TR2820 & Piraziz & Narlık \\
\hline G21 & TR2821 & Yağlıdere & Hisarcık \\
\hline G22 & TR2822 & Güce & Findıklı \\
\hline G23 & TR2823 & Doğankent & Güdül \\
\hline G24 & TR2824 & Doğankent & Çatak \\
\hline Ç1 & & Bolero & \\
\hline Ç2 & & Utrilla & \\
\hline Ç3 & & Sprinter & \\
\hline
\end{tabular}

\section{Yöntem}

Deneme 20 Kasım 2012 tarihinde kurulmuştur. Denemeye alınan genotiplerin tohumları sıra arası $40 \mathrm{~cm}$, sıra üzeri $10 \mathrm{~cm}$, sıraların uzunluğu $4 \mathrm{~m}$ ve her genotip 2 sira olacak şekilde Augmented Deneme Desenine göre kurulmuştur. Parsel alanı $0.4 \times 0.1 \times 4 \times 2=3.2 \mathrm{~m}^{2}$ olup her parselde 40 bitki olması amaçlanarak açılan karıklara 2'şer tohum bırakılmış, çıkıştan sonra tekleme işlemi yapılmıştır. Toplam 24 genotip ve 3 ticari çeşitin olduğu deneme alanımız $172.8 \mathrm{~m}^{2}$ dir. Deneme alanına ekim öncesi toprak işleme sırasında $3-4 \mathrm{~kg} / \mathrm{da} \mathrm{N}, 8-10 \mathrm{~kg} / \mathrm{da}$ $\mathrm{P}_{2} \mathrm{O}_{5}, 20 \mathrm{~kg} /$ da $\mathrm{K}_{2} \mathrm{O}$ gübreleri verilmiştir (Anonim, 2006). Yabancı ot mücadelesi çapa ile yapılmıştır. Kışlık ekim yapıldığından sulama yapılmamıştır. Bitkiler kuru hasat olgunluğu dönemine geldiklerinde elle hasat edilmiştir. Hasat esnasında parsel başlarından ve sonlarından $0.5 \mathrm{~cm}$ kenar tesiri bırakılmıştır. Ekilen genotiplerde çıkıştan hasada kadarki dönemde Salk, (1971), Gülümser (1981), Özalp (1993), Demirci ve Ünver, (1997) ve Akçin (1974) gibi çeşitli araştırıcıların ve Gıda Tarım ve Hayvancılık Bakanlığı Tohumluk Tescil ve
Sertifikasyon Merkezi Müdürlüğü'nün Tarımsal Değerleri Ölçme Denemeleri Teknik Talimatı'nın (Anonim, 2001) belirttiği şekilde Çıkış Süresi, Çiçeklenme Süresi, Vejetasyon Süresi gibi fenolojik ve Bitki Boyu (cm), Gövde Çapı (mm), Büyüme Tipi, Yaprak Rengi (Yeşil rengin yoğunluğu), Yaprak Ayası Kalınlığı, Çiçek Renkleri, Olgunlaşmamış Baklanın Rengi, Olgun Baklanın Rengi, Baklanın Kesit Şekli, Tohum Şekli, Tohum Kabuğu Yüzeyi, Dal Sayısı (adet/bitki), İlk Bakla Yüksekliği (cm), Bakla Boyu (cm), Bakla Genişliği (mm), Tohum Uzunluğu (mm), Tohum Genişliği (mm) gibi morfolojik gözlemlere ait ölçümler yapılmıştır.

İstatistiksel değerlendirmede SPSS 15.0 paket programı, Microsoft Excel programı ve SAS-JMP.50 paket programı kullanılmıştır (SPSS, 2006).

\section{Bulgular ve Tartışma}

\section{Fizyolojik gözlemler}

Yapılan çalışmada çıkış süresi, çiçeklenme süresi ve vejetasyon süresine ilişkin ortalamalar Çizelge 2'de verilmiştir. 
Çizelge 2. Bezelye çeşit ve genotiplerinin çıkış, çiçeklenme ve vejetasyon süresine ait veriler

\begin{tabular}{|c|c|c|c|c|}
\hline Genotip & Kod & Çıkış süresi (Gün) & Çiçeklenme süresi(Gün) & Vejetasyon süresi (Gün) \\
\hline $\mathrm{G} 1$ & TR2801 & 10 & 86 & 174 \\
\hline G2 & TR2802 & 15 & 95 & 185 \\
\hline G3 & TR2803 & 15 & 110 & 170 \\
\hline G4 & TR2804 & 19 & 115 & 180 \\
\hline G5 & TR2805 & 16 & 120 & 190 \\
\hline G6 & TR2806 & 17 & 125 & 195 \\
\hline G7 & TR2807 & 15 & 120 & 190 \\
\hline G8 & TR2808 & 12 & 110 & 185 \\
\hline G9 & TR2809 & 15 & 122 & 195 \\
\hline G10 & TR2810 & 19 & 120 & 185 \\
\hline G11 & TR2811 & 17 & 130 & 195 \\
\hline G12 & TR2812 & 15 & 120 & 190 \\
\hline G13 & TR2813 & 17 & 130 & 200 \\
\hline G14 & TR2814 & 19 & 140 & 205 \\
\hline G15 & TR2815 & 16 & 130 & 180 \\
\hline G16 & TR2816 & 15 & 120 & 190 \\
\hline G17 & TR2817 & 17 & 135 & 200 \\
\hline G18 & TR2818 & 12 & 110 & 180 \\
\hline G19 & TR2819 & 16 & 125 & 185 \\
\hline G20 & TR2820 & 19 & 145 & 210 \\
\hline G21 & TR2821 & 15 & 120 & 200 \\
\hline G22 & TR2822 & 12 & 105 & 175 \\
\hline G23 & TR2823 & 12 & 110 & 180 \\
\hline G24 & TR2824 & 15 & 115 & 195 \\
\hline Ç1 & Bolero & 10 & 65 & 160 \\
\hline Ç2 & Utrilla & 12 & 70 & 165 \\
\hline Ç3 & Sprinter & 15 & 110 & 190 \\
\hline Ortalama & & 15.07 & 114.92 & 187 \\
\hline
\end{tabular}

\section{Çıkış süresi}

Denemeye alınan genotip ve çeşitlerin çıkış süresi (gün) değerleri çizelge 2' de verilmiştir.

Çizelge 2 incelendiğinde ticari çeşitlerin çıkış süresi bakımından değişim aralıkları 10-15 gün arasında olduğu gözlenmiştir. Sprinter çeşidi 15 gün ortalama ile çıkış süresinin en uzun olduğu, Bolero çeşidinin ise 10 gün ortalama ile çıkış süresinin en kısa olduğu gözlenmiştir. Bezelye genotipleri incelendiğinde ise çıkış süresi bakımından 10-19 gün arasında değişim gözlenmiştir. G4, G10, G14 ve G20 genotipleri 19 gün ortalama ile çıkış süresi en uzun, G1 genotipi ise 10 gün ortalama ile çıkış süresinin en kısa olduğu gözlemlenmiştir.

Konuyla ilgili araștırmacılardan; Fidan (1999), 14-19 gün, Seyis (1994), 22.3-27 gün, Girgel (2006), ortalama 9.30 gün olarak belirlemiştir. Çalışmamızdaki çıkış süreleri, belirtilen araştırmacıların sonuçları ile uyum sağlamaktadır.

\section{Çiçeklenme süresi}

Denemeye alınan genotip ve çeşitlerin çiçeklenme süresi (gün) değerleri çizelge 2' de verilmiştir.

Çizelge 2 incelendiğinde ticari çeşitlerin çiçeklenme süresi 65-110 gün arasında değişim gösterdiği görülmüştür. Sprinter çeşidi 110 gün ortalama ile çiçeklenme süresi en uzun, Bolero çeşidi ise 65 gün ortalaması ile çiçeklenme süresi en kısa olduğu gözlenmiştir. Bezelye genotiplerinin ise çiçeklenme süresi 65-145 gün arasında değişim gösterdiği görülmüştür. Genotiplerden G20 genotipi 145 gün ortalaması ile çiçeklenme süresi en uzun, G1 genotipi ise 86 gün ortalaması ile çiçeklenme süresi en kısa olduğu gözlenmiştir.

Konuyla ilgili yapılan çalışmalarda Malhotra ve ark., (1990), 113-152 gün, Anlarsal ve ark., (2001), 83.7 gün, Qasim ve ark., (2001), 138-152 gün, Seyis, (1994), 65.67 - 70.33 gün, Fidan, (1999), 50-71 gün değişim aralığı gözlemlemişlerdir. Çalışmamızdaki değerler tespit edilen değerlerin bazılarıyla uyumlu iken bazılarıyla uyum sağlamamaktadır. Bu uyumsuzluğun, denemenin yürütüldüğü yerin toprak yapısı, çevre koşulları ve genetik özelliklerin farklı olmasından kaynaklandığı sanılmaktadır.

\section{Vejetasyon süresi}

Çizelge 2 incelendiğinde ticari çeşitlerin vejetasyon süresi 160-190 gün arasında değiştiği görülmüştür. Ticari çeşitlerden Sprinter 190 gün ortalaması ile vejetasyon süresinin en uzun, Bolero 160 gün ortalaması ile vejetasyon süresinin en kısa olduğu gözlenmiştir. Bezelye genotipleri incelendiğinde ise vejetasyon süresi 170-210 gün arasında değişim 
gösterdiği gözlemlenmiștir. Genotiplerden G20 genotipi 210 gün ortalaması ile vejetasyon süresi en uzun olduğu, G3 genotipi ise 170 gün ortalaması ile çiçeklenme süresi en kısa olduğu gözlemlenmiştir.

Konuyla ilgili yapılan çalışmalarda vejetasyon süresini; Khvostova, (1983), 79-143 gün, Seyis, (1994), 89-110.3 gün, Qasim ve ark., (2001), 162174 gün, Ishtiaq ve ark., (2001), 151.3 gün olarak bildirmişlerdir. Çalışmamızdaki değerler tespit edilen değerler ile kısmen uyumlu olduğu görülmektedir. $\mathrm{Bu}$ farklılığın çalışmamızda kullandığımız farklı genotiplerden ve deneme alanındaki toprak yapısı ve iklim koşullarının farklılığından kaynaklandığı sanılmaktadır.

\section{Morfolojik gözlemler}

\section{Bitki Boyu}

Bitki boyu bakımından 11 ilçeden toplanan 24 tane bezelye genotip ve 3 tane ticari çeşide ait ortalama, standart hata ve varyasyon katsayısı değerleri Çizelge 3'de verilmiştir.

Çizelge 3. Bezelye çeşit ve genotiplerinin bitki boyu $(\mathrm{cm})$ ve gövde çapına ilişkin ortalama, standart hata ve varyasyon katsayısı değerleri

\begin{tabular}{|c|c|c|c|c|c|}
\hline \multirow[b]{2}{*}{ Genotip } & \multirow[b]{2}{*}{ Kod } & \multicolumn{2}{|c|}{ Bitki boyu } & \multicolumn{2}{|c|}{ Gövde Capı } \\
\hline & & Ort. \pm Std.Hata & C.V. (\%) & Ort. \pm Std.Hata & C.V. (\%) \\
\hline G1 & TR2801 & $59.65 \pm 1.04$ & 7.86 & $4.10 \pm 0.10$ & 10.92 \\
\hline $\mathrm{G} 2$ & TR2802 & $63.90 \pm 1.04$ & 1.02 & $4.00 \pm 0.10$ & 11.45 \\
\hline G3 & TR2803 & $124.40 \pm 2.93$ & 8.45 & $5.79 \pm 0.04$ & 3.81 \\
\hline G4 & TR2804 & $125.60 \pm 2.73$ & 9.74 & $5.56 \pm 0.13$ & 10.58 \\
\hline G5 & TR2805 & $130.25 \pm 1.75$ & 6.03 & $5.90 \pm 0.30$ & 23.01 \\
\hline G6 & TR2806 & $125.35 \pm 1.33$ & 4.77 & $5.12 \pm 0.09$ & 8.51 \\
\hline G7 & TR2807 & $115.70 \pm 1.34$ & 5.20 & $5.56 \pm 0.18$ & 14.49 \\
\hline G8 & TR2808 & $62.55 \pm 1.82$ & 13.01 & $4.16 \pm 0.11$ & 12.55 \\
\hline G9 & TR2809 & $119.25 \pm 1.54$ & 5.20 & $6.69 \pm 0.11$ & 7.57 \\
\hline G10 & TR2810 & $87.55 \pm 1.83$ & 9.36 & $5.40 \pm 0.10$ & 9.01 \\
\hline G11 & TR2811 & $114.90 \pm 1.52$ & 5.92 & $6.11 \pm 0.14$ & 10.67 \\
\hline G12 & TR2812 & $119.60 \pm 0.92$ & 3.46 & $5.81 \pm 014$ & 11.13 \\
\hline G13 & TR2813 & $121.85 \pm 1.82$ & 6.70 & $5.53 \pm 0.09$ & 7.81 \\
\hline G14 & TR2814 & $115.30 \pm 1.47$ & 5.70 & $5.89 \pm 0.09$ & 7.47 \\
\hline G15 & TR2815 & $118.45 \pm 1.35$ & 5.11 & $5.15 \pm 0.23$ & 20.27 \\
\hline G16 & TR2816 & $117.90 \pm 1.12$ & 4.25 & $5.34 \pm 0.10$ & 8.93 \\
\hline G17 & TR2817 & $114.35 \pm 0.94$ & 3.71 & $4.95 \pm 0.08$ & 7.54 \\
\hline G18 & TR2818 & $89.80 \pm 1.18$ & 5.92 & $4.84 \pm 0.06$ & 6.45 \\
\hline G19 & TR2819 & $115.55 \pm 1.10$ & 4.26 & $5.19 \pm 0.07$ & 6.60 \\
\hline G20 & TR2820 & $118.35 \pm 0.98$ & 3.70 & $5.07 \pm 0.08$ & 7.33 \\
\hline G21 & TR2821 & $123.35 \pm 0.98$ & 3.56 & $6.17 \pm 0.06$ & 4.53 \\
\hline G22 & TR2822 & $92.75 \pm 0.86$ & 4.18 & $6.08 \pm 0.05$ & 4.19 \\
\hline G23 & TR2823 & $93.40 \pm 0.92$ & 4.41 & $5.06 \pm 0.08$ & 7.38 \\
\hline G24 & TR2824 & $111.90 \pm 0.87$ & 3.47 & $7.20 \pm 0.09$ & 6.134 \\
\hline Ç1 & Bolero & $56.75 \pm 0.96$ & 7.58 & $4.07 \pm 0.06$ & 7.67 \\
\hline Ç2 & Utrilla & $60.85 \pm 1.27$ & 9.34 & $5.20 \pm 0.07$ & 6.58 \\
\hline Ç3 & Sprinter & $85.10 \pm 1.39$ & 7.35 & $4.16 \pm 0.11$ & 12.55 \\
\hline Ortalama & & $103.12 \pm 1.04$ & 23.59 & $5.33 \pm 0.04$ & 17.90 \\
\hline
\end{tabular}

Çizelge 3 incelendiğinde ticari çeşitlerin bitki boyu bakımından 56.75-85.10 cm arasında değişim gözlenmiştir. Ticari çeşitlerden Sprinter $85.10 \mathrm{~cm}$ ortalama ile bitki boyunun en yüksek olduğu, Bolero $56.75 \mathrm{~cm}$ ortalama ile bitki boyunun en düşük olduğu bulunmuştur. Bezelye genotipleri bitki boyu bakımından 59.65-130.25 cm arasında değişim göstermiştir. Genotiplerden G5 genotipi $130.25 \mathrm{~cm}$ ortalama ile bitki boyu en yüksek olduğu, G1 genotipi ise $59.65 \mathrm{~cm}$ ortalama ile bitki boyu en düşük olduğu bulunmuştur. Genotiplerin varyasyon katsayları incelendiğinde G8 genotipi \%13.01 ortalaması ile en yüksek, G2 genotipi ise \%1.02 ortalaması ile en düşük varyasyon katsayısına sahip olduğu bulunmuştur. Konuyle ilgili yapılan çalışmalarda bezelyede bitki boyunu Karayel (2006), 40-180 cm, Gülümser ve ark. (1994), 59,2-138,2 cm, Kazemekas ve ark. (1998), 65-195 cm, Qasim ve ark. (2001), 87.3 ile $216 \mathrm{~cm}$ arasında varyasyon gösterdiğini bildirmişlerdir. Bitki boyu genetik yapısının yanı sıra çevresel faktörlerden ve yetiştirme koşullarından etkilenen bir özellik olduğu görülmektedir.

\section{Gövde çapı}

Çizelge 3 incelendiğinde ticari çeşitlerin gövde çapı 4.00-5.20 mm arasında değişim göstermiştir. Ticari çeşitlerden Utrilla $5.20 \mathrm{~mm}$ ortalaması ile gövde çapı en yüksek bulunmuştur. Bezelye genotiplerinin 
gövde çapı 4.00-7.20 $\mathrm{mm}$ arasında değişim göstermiştir. Genotiplerden G24 genotipi $7.20 \mathrm{~mm}$ ortalaması ile gövde çapı en yüksek, G2 genotipi ise $4.00 \mathrm{~mm}$ ortalaması ile gövde çapı en düşük bulunmuştur. Genotiplerin varyasyon katsayıları incelendiğinde G5 genotipi \%23.01 ortalaması ile en yüksek, G3 genotipi ise \%3.81 ortalaması ile en düşük varyasyon katsayısına sahip olduğu bulunmuştur. Konuyla ilgili yapılan çalışmalarda gövde çapını Girgel, (2006), 3.55-5.25 mm, Şalk, (1971), 2.51-7.06 $\mathrm{mm}$ arasında bildirmişlerdir. Bulgularımızla belirtilen araştırmacıların sonuçları arasında kısmen benzerlik olduğu görülmektedir.

\section{Büyüme tipi}

Denemeye alınan bezelye çeşit ve genotiplerinin büyüme tipine ilişkin gözlemler Çizelge 4 . de verilmiştir.

Çizelge 4. Bezelye genotip ve çeşitlerin büyüme tipi, yaprak rengi, yaprak ayası kalınlığl, çiçek renklerine ilişkin gözlemler

\begin{tabular}{|c|c|c|c|c|c|}
\hline Genotip & Kod & Büyüme Tipi & Yaprak Rengi & Yaprak Ayası Kalınlığı & Çiçek Renkleri \\
\hline G1 & TR2801 & Bodur & Koyu yeşil & cariaceous(kalın) & beyaz \\
\hline $\mathrm{G} 2$ & TR2802 & Bodur & Koyu yeșil & cariaceous(kalın) & beyaz \\
\hline G3 & TR2803 & Sirık & Açık yeşil & intermediate(orta) & Mor \\
\hline G4 & TR2804 & Sirık & Açık yeşil & intermediate(orta) & Mor \\
\hline G5 & TR2805 & Sirık & Orta yeşil & intermediate(orta) & Açlk mor \\
\hline G6 & TR2806 & Sirık & Orta yeşil & membranous(zarımsı) & Açlk mor \\
\hline G7 & TR2807 & Sirık & Orta yeşil & intermediate(orta) & Mor-Beyaz \\
\hline G8 & TR2808 & Bodur & Orta yeşil & cariaceous(kalın) & Beyaz \\
\hline G9 & TR2809 & Sirık & Orta yeșil & intermediate(orta) & Pembe \\
\hline G10 & TR2810 & Bodur & Koyu yeşil & cariaceous(kalın) & Beyaz \\
\hline G11 & TR2811 & Sirık & Açık yeşil & membranous(zarımsı) & Pembe \\
\hline G12 & TR2812 & Sirık & Orta yeşil & intermediate(orta) & Beyaz \\
\hline G13 & TR2813 & Sirık & Koyu yeşil & cariaceous(kalın) & Beyaz \\
\hline G14 & TR2814 & Sirık & Açlk yeşil & membranous(zarımsı) & Pembe \\
\hline G15 & TR2815 & Sirık & Açık yeşil & membranous(zarımsı) & Açlk mor \\
\hline G16 & TR2816 & Sirık & Orta yeșil & intermediate(orta) & Açlk mor \\
\hline G17 & TR2817 & Sirık & Açık yeşil & cariaceous(kalın) & Mor \\
\hline G18 & TR2818 & Bodur & Açık yeşil & intermediate(orta) & Açık mor \\
\hline G19 & TR2819 & Sirık & Orta yeşil & membranous(zarımsı) & Mor \\
\hline G20 & TR2820 & Sirık & Orta yeşil & cariaceous(kalın) & Mor \\
\hline G21 & TR2821 & Sirık & Orta yeșil & membranous(zarımsı) & Mor \\
\hline G22 & TR2822 & Bodur & Koyu yeşil & membranous(zarımsı) & Beyaz \\
\hline G23 & TR2823 & Bodur & Koyu yeșil & intermediate(orta) & Beyaz \\
\hline G24 & TR2824 & Sirık & Açık yeşil & cariaceous(kalın) & Mor \\
\hline Ç1 & Bolero & Bodur & Koyu yeşil & cariaceous(kalın) & Beyaz \\
\hline Ç2 & Utrilla & Bodur & Koyu yeșil & cariaceous(kalın) & Beyaz \\
\hline Ç3 & Sprinter & Bodur & Orta yeșil & intermediate(orta) & Beyaz \\
\hline
\end{tabular}

Çizelge 4'de görüldüğü gibi çeşit ve genotiplerde büyüme tipi bodur ve sırık karakterde oluşmuştur. Denememizde sırık türlerin çoğunlukta olduğu gözlenmiştir. Çalışmamızdaki ticari çeşitlerin hepsi bodur büyüme tipi göstermektedir. Geniș alanlarda özellikle de kuru taneye yönelik çalıșmalarda bodur özellik gösterenler tercih nedeni iken yemlik karıșık ekimlerde sırık tipler kullanılmaktadır.

\section{Yaprak rengi (yeşil rengin yoğunluğu)}

Yaprak rengine ilişkin gözlemler Çizelge 4'de verilmiştir. Çizelgeden anlaşılacağı üzere çeşit ve genotiplerde açık, orta ve koyu yeşil renkleri gözlemlenmiştir. Denememizdeki çeşit ve populasyoların yaprak renkleri 6 adet koyu yeşil, 10 adet orta yeşil, 8 adet açık yeşil renk olduğu gözlemlenmiştir. Yaprak rengi çeşitlere göre değişen kalıtsal bir özelliktir.

\section{Yaprak ayası kalınlığı}

Çizelgeden 4'ten anlaşılacağı üzere çeşit ve genotiplerde yaprak kalınlığı kalın, orta, zarımsı olarak gözlemlenmiştir. Çalışmamızda çeşit ve genotiplerin yaprak ayası kalınlıkları \%37.03 oranında cariaceous (kalın), \%37.03 oranında intermediate (orta), \%25.94 oranında membranous (zarımsı) olduğu gözlemlenmiştir. Yaprak ayası kalınlığı bitkinin genetik yapısına göre değișen bir özelliktir

\section{Çiçek renkleri}

Farklı bezelye çeşit ve genotiplerinin çiçek renklerine ilişkin gözlemler çizelge 4'de verilmiştir. Çizelgeden anlaşılacağı üzere çiçek renkleri beyaz, mor, açık mor ve pembe olarak gözlemlenmiștir. Çalıșmamızda çeşit ve genotiplerin çiçek renkleri 11 adet beyaz, 7 adet mor, 5 adet açık mor, 2 adet 
pembe renk olduğu gözlemlenmiştir. Çiçek renkleri bitkinin genetik yapısına göre değișen kalıtsal bir özelliktir.

\section{Olgunlaşmamış baklanın rengi}

Farklı bezelye çeşit ve genotiplerinin olgunlaşmamış bakla renklerine ilişkin gözlemler Çizelge 5'de verilmiştir. Denememizdeki bezelye genotiplerinin olgunlaşmamış bakla renkleri 1 adet (\%3.27) sarımsı, 4 adet (\%14.81) sarı, 22 adet (\%81.92) yeşil renk gözlemlenmiştir. Aynı çevre koşullarında yetiștirilmelerine rağmen renklerde gözlemlenen farklılığın genetik yapıdan kaynaklandığı düşünülmektedir.

\section{Olgun baklanın rengi}

Farklı çeşit ve genotiplerin olgun baklanın renklerine ilişkin gözlemler çizelge 5'de verilmiştir. Denememizde olgun bakla renkleri 12 adet (\%44.44) koyu sarımsı kahve, 3 adet (\%14.81) soluk kahve, 9 adet (\%33.33) saman sarısı, 2 adet (\%7.42) sarı olarak gözlemlenmiștir.

\section{Baklanın kesit şekli}

Bezelye çeşit ve genotiplerinin bakla kesit şekline ilişkin gözlemler çizelge 5'de verilmiştir. Çalışmamızdaki çeşit ve genotplerin baklalarının kesit şekli 14 adet (\%51.85) oval, 8 adet (\%29.62) yassı,5 adet (\%18.53) oranında yuvarlak olarak gözlemlenmiştir. Baklanın kesit şekli kalıtsal bir karakter olduğundan genetik yapıya göre değişmektedir.

\section{Tohum şekli}

Bezelye çeşit ve genotiplerinin tohum şekline ilişkin gözlemler çizelge 5'de verilmiştir. Denememizdeki çeşit ve genotiplerin tohum şekli 3 adet (\%14.81) köşeli, 21 adet (\%85.18) yuvarlak olarak gözlemlenmiştir. Kuru taneye yönelik çalışmalarda özellikle konservelik üretimlerde en çok tercih edilen tohum şekli yuvarlak olarak bilinmektedir. Denememizde ticari çeşitlerin tohum şekli yuvarlak iken yerel genotiplerin tohum şeklinin köşeli ve yuvarlak olarak farklılık göstermesi dikkat çekmiştir.

\section{Tohum kabuğu yüzeyi}

Tohum kabuğu yüzeyine ilişkin gözlemler çizelge 5'de verilmiştir. Denememizdeki çeşit ve genotiplerin hepsi tohum kabuğu yüzeyi düz olarak gözlemlenmiştir. Çalışmamızdaki çeşit ve genotipler tohum kabuğu yüzeyi bakımından aynı karakteri taşımaktadır.

\section{Dal sayısı}

Dal sayısına (adet/bitki) ait ortalama, standart hata ve varyasyon katsayısı değerleri Çizelge 6'da verilmiştir.

Çizelge 5. Bezelye genotip ve çeşitlerin olgunlaşmamış baklanın rengi, olgun baklanın rengi, baklanın kesit şekli, tohum şekli ve tohum kabuğu yüzeyine ilişkin gözlemler

\begin{tabular}{|c|c|c|c|c|c|c|}
\hline Genotip & Kod & $\begin{array}{l}\text { Olgunlaşmamış } \\
\text { Baklanın Rengi }\end{array}$ & $\begin{array}{c}\text { Olgun Baklanın } \\
\text { Rengi }\end{array}$ & $\begin{array}{c}\text { Baklanın Kesit } \\
\text { Şekli }\end{array}$ & Tohum Şekli & $\begin{array}{c}\text { Tohum Kabuğu } \\
\text { Yüzeyi }\end{array}$ \\
\hline G1 & TR2801 & Yeșil & Koyu sarımsı kahve & Oval & Köșeli & Düz \\
\hline $\mathrm{G} 2$ & TR2802 & Yeșil & Saman sarısı & Oval & Yuvarlak & Düz \\
\hline G3 & TR2803 & Yeșil & Soluk kahve & Yassı & Yuvarlak & Düz \\
\hline G4 & TR2804 & Yeșil & Soluk kahve & Oval & Köșeli & Düz \\
\hline G5 & TR2805 & Yeșil & Soluk kahve & Oval & Yuvarlak & Düz \\
\hline G6 & TR2806 & Yeşil & Sarı & Yassı & Yuvarlak & Düz \\
\hline G7 & TR2807 & Sarımsı & Saman sarısı & Oval & Yuvarlak & Düz \\
\hline G8 & TR2808 & Yeșil & Koyu sarımsı kahve & Yuvarlak & Yuvarlak & Düz \\
\hline G9 & TR2809 & Yeșil & Koyu sarımsı kahve & Yassı & Yuvarlak & Düz \\
\hline G10 & TR2810 & Sarı & Kuyu sarımsı kahve & Oval & Köşeli & Düz \\
\hline G11 & TR2811 & Yeșil & Saman sarısı & Oval & Yuvarlak & Düz \\
\hline G12 & TR2812 & Yeșil & Saman sarısı & Oval & Yuvarlak & Düz \\
\hline G13 & TR2813 & Yeşil & Koyu sarımsı kahve & Yuvarlak & Yuvarlak & Düz \\
\hline G14 & TR2814 & Sarı & Koyu sarımsı kahve & Yuvarlak & Yuvarlak & Düz \\
\hline G15 & TR2815 & Yeșil & Soluk kahve & Yuvarlak & Yuvarlak & Düz \\
\hline G16 & TR2816 & Sarı & Koyu sarımsı kahve & Yassı & Yuvarlak & Düz \\
\hline G17 & TR2817 & Yeșil & Koyu sarımsı kahve & Yassı & Yuvarlak & Düz \\
\hline G18 & TR2818 & Yeșil & Saman sarısı & Yassı & Yuvarlak & Düz \\
\hline G19 & TR2819 & Yeşil & Saman sarısı & Oval & Köşeli & Düz \\
\hline G20 & TR2820 & Yeșil & Koyu sarımsı kahve & Yassı & Yuvarlak & Düz \\
\hline G21 & TR2821 & Yeșil & Sarı & Oval & Yuvarlak & Düz \\
\hline G22 & TR2822 & Yeşil & Koyu sarımsı kahve & Oval & Yuvarlak & Düz \\
\hline G23 & TR2823 & Sarı & Saman sarısı & Yuvarlak & Yuvarlak & Düz \\
\hline G24 & TR2824 & Yeșil & Koyu sarımsı kahve & Yassı & Yuvarlak & Düz \\
\hline Ç1 & Bolero & Yeşil & Saman sarısı & Oval & Yuvarlak & Düz \\
\hline Ç2 & Utrilla & Yeșil & Saman sarısı & Oval & Yuvarlak & Düz \\
\hline Ç3 & Sprinter & Yeșil & Koyu sarımsı kahve & Oval & Yuvarlak & Düz \\
\hline
\end{tabular}


Çizelge 6. Bezelye çeşit ve genotiplerine ait dal sayısı (adet/bitki) ve ilk bakla yüksekliğine ilişkin ortalama, standart hata ve varyasyon katsayısı değerleri

\begin{tabular}{|c|c|c|c|c|c|}
\hline \multirow[b]{2}{*}{ Genotip } & \multirow[b]{2}{*}{ Kod } & \multicolumn{2}{|c|}{ Dal sayısı } & \multicolumn{2}{|c|}{ İlk bakla yüksekliği } \\
\hline & & Ort. \pm Std.Hata & C.V. $(\%)$ & Ort. \pm Std.Hata & C.V. $(\%)$ \\
\hline $\mathrm{G} 1$ & TR2801 & $3.55 \pm 0.223$ & 28.11 & $12.40 \pm 0.26$ & 9.57 \\
\hline G2 & TR2802 & $3.80 \pm 0212$ & 25.03 & $11.70 \pm 0.73$ & 8.81 \\
\hline G3 & TR2803 & $3.75 \pm 0.279$ & 33.36 & $50.45 \pm 1.34$ & 11.88 \\
\hline G4 & TR2804 & $3.35 \pm 0.220$ & 29.49 & $43.65 \pm 2.43$ & 24.93 \\
\hline G5 & TR2805 & $3.90 \pm 0.228$ & 26.15 & $55.00 \pm 1.49$ & 12.18 \\
\hline G6 & TR2806 & $4.25 \pm 0270$ & 28.43 & $51.95 \pm 1.48$ & 12.80 \\
\hline G7 & TR2807 & $3.90 \pm 0.298$ & 34.19 & $47.50 \pm 1.26$ & 11.89 \\
\hline G8 & TR2808 & $3.65 \pm 0.220$ & 27.06 & $9.70 \pm 0.65$ & 30.30 \\
\hline G9 & TR2809 & $6.75 \pm 0.446$ & 29.58 & $37.85 \pm 1.64$ & 19.40 \\
\hline G10 & TR2810 & $3.45 \pm 0.256$ & 33.21 & $21.65 \pm 1.01$ & 20.94 \\
\hline G11 & TR2811 & $6.15 \pm 0.342$ & 24.89 & $45.05 \pm 1.46$ & 14.55 \\
\hline G12 & TR2812 & $5.00 \pm 0.205$ & 18.35 & $39.95 \pm 0.68$ & 7.68 \\
\hline G13 & TR2813 & $6.30 \pm 0.300$ & 21.29 & $38.70 \pm 0.90$ & 10.50 \\
\hline G14 & TR2814 & $5.80 \pm 0.224$ & 17.33 & $33.80 \pm 1.51$ & 20.05 \\
\hline G15 & TR2815 & $5.85 \pm 0.292$ & 22.37 & $30.30 \pm 1.74$ & 25.72 \\
\hline G16 & TR2816 & $5.85 \pm 0.318$ & 24.34 & $31.40 \pm 1.40$ & 20.01 \\
\hline G17 & TR2817 & $5.30 \pm 0.241$ & 20.39 & $29.50 \pm 1.00$ & 15.17 \\
\hline G18 & TR2818 & $5.70 \pm 0.272$ & 21.37 & $20.35 \pm 0.87$ & 19.28 \\
\hline G19 & TR2819 & $5.90 \pm 0.315$ & 23.90 & $39.30 \pm 0.97$ & 11.04 \\
\hline G20 & TR2820 & $3.05 \pm 0.198$ & 29.08 & $34.85 \pm 1.00$ & 12.94 \\
\hline G21 & TR2821 & $4.30 \pm 0.123$ & 23.97 & $40.65 \pm 0.75$ & 8.34 \\
\hline G22 & TR2822 & $5.55 \pm 0.184$ & 14.87 & $18.40 \pm 0.90$ & 21.98 \\
\hline G23 & TR2823 & $4.15 \pm 0.243$ & 26.25 & $27.85 \pm 1.05$ & 16.89 \\
\hline G24 & TR2824 & $5.95 \pm 0.294$ & 22.11 & $39.55 \pm 1.02$ & 11.61 \\
\hline Ç1 & Bolero & $12.80 \pm 0.587$ & 20.52 & $39.35 \pm 0.77$ & 8.77 \\
\hline Ç2 & Utrilla & $6.80 \pm 0.277$ & 18.23 & $20.55 \pm 1.09$ & 23.91 \\
\hline Ç3 & Sprinter & $3.65 \pm 0.220$ & 27.07 & $9.70 \pm 0.65$ & 30.30 \\
\hline Ortalama & & $5.12 \pm 0.097$ & 44.17 & $32.63 \pm 0.60$ & 42.97 \\
\hline
\end{tabular}

Çizelge 6 incelendiğinde ticari çeşitlerin dal sayısı 3.65-12.80 adet/bitki arasında değişim göstermiştir. Ticari çeşitlerden en fazla dal sayısı 12.80 adet/bitki ile Bolero çeşidi, en az dal sayısı ise 3.65 adet/bitki ile Sprinter çeşidi olarak bulunmuștur. Bezelye genotipleri dal sayısı bakımından 3.05-6.75 adet/bitki arasında değişim göstermiştir. Genotiplerden en fazla dal sayısı 6.75 adet/bitki ile G9 genotipi, en az dal sayısı ise 3.05 adet/bitki ile G20 genotipi olduğu bulunmuştur. Genotiplerin varyasyon katsayıları incelendiğinde G7 genotipi $\% 34.19$ ortalaması ile en yüksek, G22 genotipi ise \%14.87 ortalaması ile en düşük varyasyon katsayısına sahip olduğu bulunmuştur.

Dallanma, bezelye bitkisinde genelde gövdenin üst kısmında gerçekleştiği (Akçin, 1988) bildirilmektedir. Çalışmamızda genotipler arasında alt kısımdan da dallanma olduğu gözlenmiştir. Konuyla ilgili yapılan çalışmalarda dal sayısını Karayel, (2006), 1-13 adet/bitki, Tosun ve Sepetoğlu, (1990), ortalama 2.1 adet/bitki, Girgel, (2006), ortalama 15.37 adet/bitki olarak belirlemişlerdir. Yapılan çalışmalarda da görüldüğü gibi dal sayılarında farklı değerler bulunmaktadır. $\mathrm{Bu}$ farklılıkların çevresel ve genetik faktörlerden kaynaklandığı sanılmaktadır.

\section{İlk bakla yüksekliği}

Denemeye alınan bezelye çeşit ve genotiplerinin ilk bakla yüksekliğine $(\mathrm{cm})$ ait ortalama, standart hata ve varyasyon katsayısı değerleri Çizelge 6'da verilmiştir. Çizelge 6 incelendiğinde ticari çeşitlerin ilk bakla yüksekliği 9.70-39.35 cm arasında değişim göstermiştir. Ticari çeşitlerden Sprinter $39.35 \mathrm{~cm}$ ortalaması ile ilk bakla yüksekliği en yüksek olduğu, Bolero ise $9.70 \mathrm{~cm}$ ortalaması ile ilk bakla yüksekliği en düşük olduğu bulunmuştur. Bezelye genotipleri ilk bakla yüksekliği bakımından 9.70-50.45 cm arasında değişim göstermiştir. Genotiplerden G3 genotipi $50.45 \mathrm{~cm}$ ortalaması ile ilk bakla yüksekliği en yüksek olduğu, G8 genotipi ise $9.70 \mathrm{~cm}$ ortalaması ile ilk bakla yüksekliği en düşük olduğu tespit edilmiştir. Genotiplerin varyasyon katsayıları incelendiğinde G8 genotipi \%30.30 ortalaması ile en yüksek, G12 genotipi ise \%7.68 ortalaması ile en düşük varyasyon katsayısına sahip olduğu bulunmuştur. Araştırmacılardan Girgel, (2006), çalışmasında ilk bakla yüksekliğinin ortalaması $41.23 \mathrm{~cm}$ olarak bildirmiştir. Çalışmamızdaki değerlerle uyum sağlamaktadır. İlk bakla 
yüksekliğinin bitki boyuna göre değiștiği gözlenmiştir. İlk bakla yüksekliği ile bitki boyu arasında doğru orantı bulunmaktadır.

\section{Bakla boyu}

Denemeye alınan bezelye çeşit ve genotiplerinin bakla boyu $(\mathrm{cm})$ ortalamass, standart hata ve varyasyon katsayısı değerleri Çizelge 7'de verilmiştir. Çizelge 7. incelendiğinde ticari çeşitler bakla boyu 7.00-8.30 cm arasında değişim göstermiştir. Ticari çeşitlerden Utrilla $8.30 \mathrm{~cm}$ ortalama ile bakla boyunun en yüksek olduğu, Bolero ise $7.00 \mathrm{~cm}$ ortalama ile bakla boyunun en düşük olduğu bulunmuştur. Bezelye genotipleri incelendiğinde bakla boyu bakımından 6.45-11.25 cm arasında değișim göstermiștir. Genotiplerden G12 genotipi $11.25 \mathrm{~cm}$ ortalama ile bakla boyunun en yüksek olduğu, G22 genotipleri ise $6.45 \mathrm{~cm}$ ortalama ile bakla boyunun en düşük olduğu tespit edilmiştir. Genotiplerin varyasyon katsayıları incelendiğinde G9 genotipi \%19.87 ortalaması ile en yüksek, G1 genotipi ise \%8.73 ortalaması ile en düșük varyasyon katsayısına sahip olduğu bulunmuştur. Konuyla ilgili yapılan araştırmalarda bakla boynu, Günay (1983), 3-15 cm, Ergun ve ark., (1986), 6.6-11.5 cm, Gülümser ve ark., (1994), 7,75 cm, Fidan, (1999), 5.89-8.39 cm, Girgel, (2006), ortalama $7.04 \mathrm{~cm}$, Qasim ve ark., (2001), 10,7 cm olarak bulmuşlardır. Tespit edilen bu değerleri elde ettiğimiz değerlerle karşılaştırdığımızda Günay, (1983), Ergun ve ark., (1986), Qasim ve ark., (2001), uyum halinde olduğu, Fidan, (1999), ile farklı olduğu görülmektedir. Bu farklılığın genetik ve ekolojik şartlardan kaynaklandığı sanılmaktadır.

\section{Tohum boyu}

Denemeye alınan bezelye çeşit ve genotiplerinin tohum boyuna (mm) ait ortalama, standart hata ve varyasyon katsayısı değerleri Çizelge 8'de verilmiştir. Çizelge 8 incelendiğinde ticari çeșitlerin tohum boyu 8.95-10.095 $\mathrm{mm}$ arasında değişim göstermiştir. Ticari çeşitlerden Utrilla'nın 10.095 mm ortalama ile tohum boyunun en yüksek, Sprinter'in $8.95 \mathrm{~mm}$ ortalama ile tohum boyunun en düşük olduğu bulunmuştur. Bezelye genotipleri incelendiğinde tohum boyu 6.924-11.103 mm arasında değişim göstermiştir. Genotiplerden G12 genotipi $11.103 \mathrm{~mm}$ ortalama ile tohum boyunun en yüksek olduğu, G4 genotipi ise $6.924 \mathrm{~mm}$ ortalama ile tohum boyunun en düşük olduğu bulunmuştur. Genotiplerin varyasyon katsayıları incelendiğinde G1 genotipi \%13.95 ortalaması ile en yüksek, G16 genotipi ise \%3.14 ortalaması ile en düşük varyasyon katsayısına sahip olduğu bulunmuştur.

Çizelge 7. Bezelye çeşit ve genotiplerine ait bakla boyu $(\mathrm{cm})$ ve bakla genişliğine (mm) ilişkin ortalama, standart hata ve varyasyon katsayısı değerleri

\begin{tabular}{|c|c|c|c|c|c|}
\hline \multirow[b]{2}{*}{ Genotip } & \multirow[b]{2}{*}{ Kod } & \multicolumn{2}{|c|}{ Bakla boyu } & \multicolumn{2}{|c|}{ Bakla genişliği } \\
\hline & & Ort. \pm Std.Hata & C.V. (\%) & Ort. \pm Std.Hata & C.V. (\%) \\
\hline $\mathrm{G} 1$ & TR2801 & $7.57 \pm 0.148$ & 8.73 & $10.719 \pm 0.079$ & 3.31 \\
\hline $\mathrm{G} 2$ & TR2802 & $6.80 \pm 0.224$ & 14.78 & $10.510 \pm 0.092$ & 3.93 \\
\hline G3 & TR2803 & $8.15 \pm 0.264$ & 14.50 & $17.715 \pm 0.134$ & 3.38 \\
\hline G4 & TR2804 & $7.50 \pm 0.276$ & 16.47 & $14.183 \pm 0.339$ & 10.69 \\
\hline G5 & TR2805 & $8.30 \pm 0.252$ & 13.59 & $13.478 \pm 0.158$ & 5.25 \\
\hline G6 & TR2806 & $7.90 \pm 0.289$ & 16.37 & $12.688 \pm 0.277$ & 9.77 \\
\hline G7 & TR2807 & $7.40 \pm 0.284$ & 17.20 & $10.582 \pm 0.133$ & 5.63 \\
\hline G8 & TR2808 & $7.95 \pm 0.303$ & 17.06 & $11.643 \pm 0.175$ & 6.75 \\
\hline G9 & TR2809 & $7.35 \pm 0.326$ & 19.87 & $13.094 \pm 0.171$ & 5.85 \\
\hline G10 & TR2810 & $8.20 \pm 0.277$ & 15.11 & $10.954 \pm 0.152$ & 6.21 \\
\hline G11 & TR2811 & $6.60 \pm 0.197$ & 13.37 & $11.804 \pm 0.122$ & 4.64 \\
\hline G12 & TR2812 & $11.25 \pm 1.144$ & 16.73 & $11.613 \pm 0.122$ & 4.70 \\
\hline G13 & TR2813 & $7.75 \pm 0.279$ & 16.14 & $12.792 \pm 0.203$ & 7.123 \\
\hline G14 & TR2814 & $7.45 \pm 0.198$ & 11.91 & $10.874 \pm 0.127$ & 5.23 \\
\hline G15 & TR2815 & $8.15 \pm 0.264$ & 14.50 & $12.649 \pm 0.104$ & 3.68 \\
\hline G16 & TR2816 & $10.20 \pm 0.359$ & 15.77 & $20.914 \pm 0.39$ & 8.35 \\
\hline G17 & TR2817 & $7.90 \pm 0.270$ & 15.31 & $15.654 \pm 0.086$ & 2.47 \\
\hline G18 & TR2818 & $8.75 \pm 0.203$ & 10.40 & $20.833 \pm 0.431$ & 9.26 \\
\hline G19 & TR2819 & $8.20 \pm 0.247$ & 13.47 & $11.417 \pm 0.156$ & 6.13 \\
\hline G20 & TR2820 & $7.45 \pm 0.256$ & 15.38 & $15.239 \pm 0.075$ & 2.20 \\
\hline G21 & TR2821 & $7.90 \pm 0.250$ & 14.16 & $13.276 \pm 0.087$ & 2.96 \\
\hline G22 & TR2822 & $6.45 \pm 0.211$ & 14.64 & $12.103 \pm 0.059$ & 2.18 \\
\hline G23 & TR2823 & $8.40 \pm 0.265$ & 14.13 & $11.142 \pm 0.092$ & 3.71 \\
\hline G24 & TR2824 & $8.35 \pm 0.350$ & 18.74 & $19.112 \pm 0.263$ & 6.17 \\
\hline Ç1 & Bolero & $7.00 \pm 0.217$ & 13.90 & $9.887 \pm 0.106$ & 4.81 \\
\hline Ç2 & Utrilla & $8.30 \pm 0.291$ & 15.68 & $13.461 \pm 0.447$ & 14.87 \\
\hline Ç3 & Sprinter & $7.95 \pm 0.303$ & 17.06 & $11.643 \pm 0.175$ & 6.75 \\
\hline Ortalama & & $7.96 \pm 0.909$ & 17.64 & $13.332 \pm 0.135$ & 9.54 \\
\hline
\end{tabular}


Çizelge 8. Bezelye çeşit ve genotiplerine ait tohum boyu ( $\mathrm{mm}$ ) ve tohum genişliği (mm) ilişkin ortalama, standart hata ve varyasyon katsayısı değerleri

\begin{tabular}{|c|c|c|c|c|c|}
\hline \multirow[b]{2}{*}{ Genotip } & \multirow[b]{2}{*}{ Kod } & \multicolumn{2}{|c|}{ Tohum boyu } & \multicolumn{2}{|c|}{ Tohum genişliği } \\
\hline & & Ort. \pm Std.Hata & C.V. $(\%)$ & Ort. \pm Std.Hata & C.V. (\%) \\
\hline $\mathrm{G} 1$ & TR2801 & $7.157 \pm 0.223$ & 13.95 & $8.104 \pm 0.323$ & 17.85 \\
\hline G2 & TR2802 & $7.627 \pm 0.217$ & 12.77 & $7.978 \pm 0.230$ & 12.92 \\
\hline G3 & TR2803 & $10.472 \pm 0.087$ & 3.73 & $10.361 \pm 0.102$ & 4.437 \\
\hline G4 & TR2804 & $6.924 \pm 0.085$ & 5.50 & $7.715 \pm 0.187$ & 10.84 \\
\hline G5 & TR2805 & $10.095 \pm 0.237$ & 10.53 & $10.085 \pm 0.228$ & 10.11 \\
\hline G6 & TR2806 & $9.681 \pm 0.204$ & 9.43 & $9.784 \pm 0.182$ & 8.35 \\
\hline G7 & TR2807 & $9.561 \pm 0.189$ & 8.87 & $9.174 \pm 0.125$ & 5.87 \\
\hline G8 & TR2808 & $8.950 \pm 0.096$ & 4.80 & $9.690 \pm 0.143$ & 6.61 \\
\hline G9 & TR2809 & $10.819 \pm 0.171$ & 7.12 & $9.998 \pm 0.204$ & 9.15 \\
\hline G10 & TR2810 & $7.641 \pm 0.159$ & 9.35 & $7.585 \pm 0.237$ & 14.00 \\
\hline G11 & TR2811 & $10.121 \pm 0.12$ & 5.34 & $9.862 \pm 0.072$ & 3.27 \\
\hline G12 & TR2812 & $11.103 \pm 0.087$ & 3.45 & $10.087 \pm 0.104$ & 4.61 \\
\hline G13 & TR2813 & $10.079 \pm 0.152$ & 6.76 & $9.867 \pm 0.123$ & 5.60 \\
\hline G14 & TR2814 & $9.893 \pm 0.103$ & 4.69 & $9.843 \pm 0.097$ & 4.44 \\
\hline G15 & TR2815 & $10.507 \pm 0.089$ & 3.80 & $9.931 \pm 0.076$ & 3.44 \\
\hline G16 & TR2816 & $10.794 \pm 0.075$ & 3.14 & $10.780 \pm 0.053$ & 2.21 \\
\hline G17 & TR2817 & $9.705 \pm 0.088$ & 4.08 & $10.237 \pm 0.079$ & 3.46 \\
\hline G18 & TR2818 & $10.493 \pm 0.119$ & 5.07 & $10.748 \pm 0.113$ & 4.73 \\
\hline G19 & TR2819 & $10.134 \pm 0.087$ & 3.88 & $8.868 \pm 0.079$ & 4.02 \\
\hline G20 & TR2820 & $10.266 \pm 0.082$ & 3.60 & $10.257 \pm 0.084$ & 3.66 \\
\hline G21 & TR2821 & $10.344 \pm 0.093$ & 4.05 & $10.232 \pm 0.076$ & 3.34 \\
\hline G22 & TR2822 & $9.073 \pm 0.08$ & 3.95 & $9.072 \pm 0.085$ & 4.22 \\
\hline G23 & TR2823 & $9.075 \pm 0.086$ & 4.27 & $8.854 \pm 0.069$ & 3.48 \\
\hline G24 & TR2824 & $8.410 \pm 0.112$ & 6.00 & $8.527 \pm 0.112$ & 6.91 \\
\hline Ç1 & Bolero & $9.893 \pm 0.103$ & 4.69 & $9.843 \pm 0.979$ & 4.44 \\
\hline Ç2 & Utrilla & $10.095 \pm 0.237$ & 10.53 & $10.085 \pm 0.228$ & 10.12 \\
\hline Ç3 & Sprinter & $8.950 \pm 0.096$ & 4.80 & $9.690 \pm 0.143$ & 6.61 \\
\hline Ortalama & & $9.550 \pm 0.054$ & 13.33 & $9.528 \pm 0.047$ & 11.52 \\
\hline
\end{tabular}

\section{Tohum genişliği}

Denemeye alınan bezelye çeşit ve genotiplerinin tohum genişliğine $(\mathrm{mm})$ ait ortalama, standart hata ve varyasyon katsayısı değerleri Çizelge 8. de verilmiştir.

Çizelge 8. incelendiğinde ticari çeşitlerin tohum genişliği 9.69-10.085 mm arasında değișim göstermiștir. Ticari çeşitlerden en yüksek tohum genişliği $10.085 \mathrm{~mm}$ ile Utrilla, en düşük tohum genişliği $9.69 \mathrm{~mm}$ ile Sprinter çeşidinden tespit edilmiştir. Bezelye genotipleri incelendiğinde tohum genişliği $7.585-10.780 \mathrm{~mm}$ arasında değişim göstermiştir. Genotiplerden G16 genotipi $10.780 \mathrm{~mm}$ ortalama ile tohum genişliğinin en yüksek olduğu, G10 genotipi ise $7.585 \mathrm{~mm}$ ortalama ile tohum genişliğinin en düşük olduğu bulunmuştur. Genotiplerin varyasyon katsayıları incelendiğinde G1 genotipi \%17.85 ortalaması ile en yüksek, G16 genotipi ise \%2.21 ortalaması ile en düşük varyasyon katsayısına sahip olduğu bulunmuştur.

Bezelyede küçük taneli tiplerden iri taneli tiplere kadar geniş bir varyasyon görülebilmektedir. Tane iriliği verimi etkileyen faktörlerden biridir. Tane bezelye yetiştiriciliğinde iri tane aranılan özelliklerden biridir. Bizim çalışmamızdaki genotiplerden G18 tohum iriliği açısından ticari çeşitlere en yakın genotiptir.

\section{Sonuç ve Öneriler}

Giresun ilinde yetişen yerel bezelye (Pisum sativum L.) tiplerinin fizolojik ve morfolojik özelliklerinin belirlenmesi amacıyla yapılan bu çalışma 2012-2013 üretim sezonunda yürütülmüştür. Çalışmada bitki materyeli olarak Giresun ilinin 11 ilçesinden toplanan 24 farklı bezelye genotipi ile 3 tescilli çeşit kullanılmıştır.

Araştırma sonuçlarına göre; çıkış süresi ticari çeşitlerde 10-15 gün arasında, genotiplerde ise 1019 gün arasında değişim göstermektedir. Genotiplerden 12 tanesi ticari çeşitlerden daha geç çıkış gösterdiği gözlemlenmiştir. Çiçeklenme süresi ticari çeşitlerde 110-65 gün arasında, genotiplerde ise 145-65 gün arasında değişim göstermiştir. Genotiplerden 17 tanesi ticari çeşitlerden daha geç zamanda çiçeklendiği gözlemlenmiştir. Vejetasyon süresi ticari çeşitlerde 190-160 gün arasında, genotiplerde ise 170-210 gün arasında değişim göstermiştir. Denememizdeki 9 genotipin vejetasyon süresinin ticari çeşitlerden daha uzun olduğu gözlemlenmiştir. Denememizdeki gözlem sonuçlarına göre; büyüme tipi olarak 7 tane genotip 
bodur,17 tane genotip ise sırık gelişim göstermiştir. Yaprak rengi olarak denememizde en çok gözlenen orta yeşil (\% 40.74) renk olmuştur. Yaprak kalınlığı olarak da en çok gözlenen tip intermediate(orta) (\% 37,03) kalınlıktadır. Bakla rengi olarak çoğunluğu (19 adet) yeşil renklidir. Baklanın kesit şekli olarak 11 adet genotipte oval, gözlemlenmiştir. Tohum şekli olarak 4 tane genotip köșeli iken diğerleri yuvarlaktır. Denememizde çiçek renkleri mor, açık mor, pembe ve beyaz olarak belirlenmiştir. Genotiplerden 8 tanesinin çiçek rengi beyaz, 3 tanesinin pembe geriye kalan 13 tanesinin ise mor ve açık mor renklerdedir. Ticari çeşitlerin tamamının çiçek rengi beyazdır. Bodur büyüme tipi gösteren genotiplerin çiçek renklerinin genellikle beyaz olduğu dikkat çekmektedir. Bakla şekilleri dikkate alındığında ağırlıklı olarak araka tipi olarak nitelendirilen yani bakla kabuğu ayrılarak içleri tüketilen tipler olduğu tespit edilmiştir. Denememizdeki morfolojik gözlemlerin sonuçlarına göre; bitki boyları, ticari çeşitlerde 59.65 ile 85.10 cm arasinda, genotiplerde 59.61 ile $130.25 \mathrm{~cm}$ arasında değișim göstermiștir. Bezelye tiplerinde kısa boy ve dik gelişim genelde tarla tarımında tercih edilen bir durumdur. Çalışmamızda bu özellikte 5 genotip olduğu tespit edilmiştir. Gövde çapları, ticari çeşitlerde 4.07 ile $5.20 \mathrm{~mm}$ arasında, genotiplerde ise 4.0 ile $7.20 \mathrm{~mm}$ arasında değişim göstermiştir. Çalıștığımız genotiplerin içinde 18 tanesinin gövde çapı kullandığımız ticari çeşitleri geçmiştir. Dal sayıları, ticari çeşitlerde 3.65 ile 12.80 adet/bitki arasında, genotiplerde ise 3.05 ile 6.75 adet/bitki arasında değișim göstermiştir. Çalışmamızdaki genotipler arasında alt kısımdan da dallanma olduğu gözlenmiştir. İlk bakla yüksekliği, ticari çeşitlerde 9.70 ile $39.35 \mathrm{~cm}$ arasında, genotiplerde 9.70 ile $51.95 \mathrm{~cm}$ arasında değişim göstermiştir. Çalışmamızdaki değerlere bakıldığında ilk bakla yüksekliğinin bitki boyuna göre değiștiği gözlenmiştir. Çalıştığımız genotiplerin 19 tanesinin ilk bakla yüksekliği kullandığımız ticari çeşitleri geçmiştir. Bakla boyu, ticari çeşitlerde7.0 ile $8.30 \mathrm{~cm}$ arasında, genotiplerde 6.45 ile $11.25 \mathrm{~cm}$ arasında değişim göstermiştir. Çalıştığımız genotiplerin ticari çeşitlerle bakla boyları yakın değerlerde olduğu tespit edilmiştir. Bakla genişliği, ticari çeşitlerde 9.887 ile $13.461 \mathrm{~mm}$ arasinda, genotiplerde ise 10.510 ile $20.914 \mathrm{~mm}$ arasında değişim göstermiştir. Çalıștığımız genotiplerin 4 tanesinin bakla genişliği kullandığımız ticari çeşitleri geçmiștir. Tohum boyu, ticari çeşitlerde 8.950 ile $10.095 \mathrm{~mm}$ arasında, genotiplerde 6.924 ile $11.103 \mathrm{~mm}$ arasında değişim göstermiştir. Tohum genişliği, ticari çeşitlerde 9.690 ile $10.085 \mathrm{~mm}$, genotiplerde 7.585 ile $10.780 \mathrm{~mm}$ arasında değişim göstermiştir. Çalıştığımız genotiplerin tohum boyu ve genişliği kullandığımız ticari çeşitlere yakın değerlerdedir. Bezelye yetiştiriciliğinde yemeklik ve konservelik tiplerde tohum iriliği önemli bir özelliktir. Tanımlamasını yaptığımız yerel bezelye genotiplerinde gözlemlediğimiz tüm fizyolojik ve morfolojik özellikler içerisinde geniş bir varyasyonun olduğu tespit edilmiştir. Toplanan 24 yerel genotipin ilerde yapılacak çeşit geliştirme ya da ıslah çalışmaları için kullanılabileceği kanaatine varılmıştır.

\section{Kaynaklar}

Akçin, A., 1974. Erzurum şartlarında yetiştirilen kuru fasulye çeşitlerinde gübreleme, ekim zamanı ve sıra aralığının tane verimine etkisi ile bu çeşitlerin bazı fenolojik, morfolojik ve teknolojik karakterleri üzerine bir araştırma. Atatürk Üniversitesi Ziraat Fakültesi Yayın No: 157:1-112.

Akçin, A., 1988. Yemeklik dane baklagiller. Selçuk Üniversitesi Yayınları: 43. Ziraat Fakültesi Yayınları: 8. Konya. 377.

Akgün. İ., Tosun M., Sağsöz, S., 1998. Bitkisel gen kaynaklarının önemi ve Erzurum'un bitkisel gen kaynakları yönünden değerlendirilmesi. Doğu Anadolu Tarım Kongresi 14-18 Eylül, 1998 Erzurum, 363-372.

Anlarsal, A. E., Yücel C., Özveren D., 2001. Çukurova koşullarında bazı bezelye (Pisum Sativum Ssp. Sativum L. Ve Pisum Sativum Ssp. Avense L.) hatlarının uyumu ve verimlerinin saptanması üzerinde bir araştırma. Çukurova Üniversitesi Ziraat Fakültesi, 16(3): 11-20.

Anonim, 2001. Tarımsal değerleri ölçme denemeleri teknik talimatı. Yemeklik tane baklagiller. T.C. Tarım ve Köyişleri Bakanlığı, Koruma ve Kontrol Genel Müdürlüğü, Tohumluk Tescil ve Sertifikasyon Merkezi Müdürlüğü, Ankara.

Anonim, 2012. Fındık Araştırma Enstitüsü Toprak Analiz Laboratuvarı, Giresun.

Anonim, 2013. Ordu Meteoroloji İstasyon Müdürlüğü.

Anonim, 2016. FAO İnternet sitesi, http://www.fao.org/faostat/ (Erişim tarihi:12.09.2016).

Çiftçi C.Y., Adak M.S. 2009. Yemeklik Tane Baklagiller. Tarla Bitkileri. Ankara Üniversitesi Ziraat Fakültesi Yayınları. Yayın no: 1569. Ders kitabı: 521, $257-$ 308. 
Demirci, G., Ünver, S. 1997. Ankara koşullarında bezelye (Pisum Sativum L.)'de farklı ekim zamanlarının verim ve verim öğelerine etkileri. A.Ü. Fen Bil. Ens., Yüksek Lisans Tezi, s: 50, Ankara.

Ergun, C., Çetin, A., Fidan,F., 1986. Bazı bezelye çeşitlerinin konserveye uygunluk durumları üzerinde bir araştırma, Sonuç Raporu, Atatürk bahçe Kültürleri Araştırma Enstitüsü, Yalova.

Fidan, S., 1999. Tokat Merkez İlçe, Niksar ilçesi ve Çamlıbel Beldesi için uygun konservelik bezelye çeşitleri (Pisum Sativum L.) ve ekim zamanlarının belirlenmesi üzerine bir araștırma. Tokat, Doktora Tezi, 121.

Girgel, Ü. 2006. Kahramanmaraş koşullarında bolero bezelye (Pisum Sativum L.) çeşitinde ekim sıklığının verim ve verim özelliklerine etkisi üzerine bir araştırma. K.S.İ.Ü. Fen Bil. Ens. Yüksek Lisans Tezi, S: 48

Gülümser, A., 1981. Bezelyede Azotla Gübreleme ve Sulamanın Verim ve Verim Unsurları ile Tanenin Protein Oranına Etkileri. Doçentlik Tezi, Atatürk Üniversitesi Ziraat Fakültesi, Erzurum, 103 s.

Gülümser, A., Seyis, F., Bozoğlu, H., 1994. Samsun ekolojik şartlarında kışlık ve yazlık olarak ekilen bezelye çeşitlerinin konservecilik özellikleri ile tane veriminin tespiti. E.Ü.Z.F. Tarla Bitkileri Bölümü Tarla Bitkileri Bilim Derneği TUBİTAK ve ÜSİGEM. Tarla Bitkileri Kongresi, 25-29 Nisan 1994 Cilt I Agronomi Bildirileri, İzmir. 87-90.

Günay, A., 1983. Sebzecilik, Özel Sebze Yetiştiriciliği, Çağ Matbaası, Cilt IV, Ankara.

Ishtiaq, M., Ara N., Rashid, A., 2001. Response of different pea cultivars to various planting dates under the agro-climatic conditions of Swat. Sarhad-Journalof- Agriculture. 17(3):327-332.

Karayel R., 2006.Yerel bezelye genotiplerinin tanımlanması ve bazı agronomik özelliklerinin tespiti. Yüksek lisans tezi, Ondokuz Mayıs Üniversitesi Ziraat Fakültesi Tarla Bitkileri Bölümü, Samsun, $147 \mathrm{~s}$.
Kazemekas, O., Becius, V., Kazemekiene, B., 1998. Signifinance of productiviy elements of pea for creating new varieties. Biologija (1): 34-36.

Khvostova, V. V., 1983. Genetics and breeding of Peas. USSR Academy of Sciences. General Biology Division. U. S. D. A., Washington D. C. (Translated From Russian).TT78-52011.

Malhotra, R. S.,Slım, S. and Saxena, M. C., 1990. Dry pea improvement food legume improvement program ICARDA. Annual Repot Aleppo, Syria. S: 209-216.

Özalp, R., 1993. Farklı pix dozları ve uygulama zamanlarının gökçeada ekolojik şartlarında yetiştirilen araka grubu bezelye çeşitlerinde (Pisum sativum L.) tane verimi, protein miktarı, fenolojik ve morfolojik özellikleri üzerinde bir araștırma. Selçuk Üniv. Fen Bil. Ens. (Basılmamış Doktora Tezi), Konya.

Özgen. M., M.S. Adak., A. Karagöz., H. Ulukan., 2000. Bitkisel gen kaynaklarının korunma ve kullanımında yeni yaklaşımlar. V. Türkiye Ziraat Mühendisliği Teknik Kongresi. TMMOB Ziraat Mühendisleri Odası, Ankara. 1, 259-284.

Qasim, M., Zubair, M., Wandan, D., 2001. Evaluation of exotic cultivars of pea in Swat valley. Sarhad Journal of Agricultire 17(4): 545-548.

SPSS, 2006. SPSS Base 15.0 User's Guide, SPSS Inc., Chicago, USA.

Salk, A., 1971. Yerli ve yabancı orijinli bezelye çeşitlerinin morfolojik ve pomolojik vasıfları ile soğuğa mukavemetleri üzerine araştırmalar (Doktora Tezi). E. Ü. Fen. Bil. Ens. Bornova. İzmir.

Seyis, F., 1994. Samsun ekolojik şartlarında yazlık olarak ekilen bezelye çeşitlerinin tane verimi ile bazı önemli özellikleri ve bunlar arasındaki ilișkiler üzerine bir araștırma. Yüksek Lisans Tezi, Ondokuz Mayıs Üniversitesi Fen Bilimleri Enstitüsü, Samsun. $75 \mathrm{~s}$.

Tosun, M., Sepetoğlu H., 1990. Ekim sıklığının yapraklı ve yapraksız bezelyenin verimine etkisi üzerinde araștırmalar. Ege Üniversitesi Ziraat Fakültesi Dergisi Cilt: 27(3): 59-69. 